\title{
An assessment of the production, reproduction, and functional traits of Holstein-Friesian, Jersey $\times$ Holstein-Friesian, and Norwegian Red $\times$ (Jersey $\times$ Holstein-Friesian) cows in pasture-based systems
}

\author{
B. McClearn, ${ }^{1,2 *}$ ․ Lelaby, ${ }^{3}$ T. J. Gilliland, ${ }^{2} \oplus$ C. Guy, ${ }^{1,2}$ M. Dineen, ${ }^{1}{ }^{\oplus}$ F. Coughlan, ${ }^{1}$ F. Buckley, ${ }^{1}$ \\ and B. McCarthy ${ }^{1}$ \\ ${ }^{1}$ Teagasc, Animal and Grassland Research and Innovation Centre, Moorepark, Fermoy, Co. Cork, P61 C996, Ireland \\ ${ }^{2}$ Institute of Global Food Security, Queen's University Belfast, Belfast, BT9 5DL, Northern Ireland \\ ${ }^{3}$ INRAE, AgroCampus Ouest, Physiologie, Environnement et Génétique pour l'Animal et les Systèmes d'Elevage, St. Gilles, 35590, France
}

\begin{abstract}
Pasture-based production systems typically require highly fertile, healthy, and robust genetics, with greater emphasis on milk solids (MSo; kg of fat + protein) production as opposed to milk yield. This study assessed milk production, production efficiency, reproductive performance, body weight (BW), body condition score, and functional traits in 3 different dairy cow genotypes: Holstein-Friesian $(\mathrm{HF})$, Jersey $\times$ Holstein-Friesian $(\mathrm{JEX})$, and Norwegian Red $\times($ Jersey $\times$ HolsteinFriesian) (3-way). The 3 genotypes were rotationally grazed on 4 different grazing treatments after calving in spring and were stocked at a rate of 2.75 cows/ha. Holstein-Friesian cows produced higher daily and total milk yields compared with JEX and 3-way cows $(5,718$ vs. 5,476 and $5,365 \mathrm{~kg} /$ cow, respectively). However, JEX and 3-way cows had higher milk fat and protein contents (4.86 and $4.75 \%$, respectively, for JEX and 3.87 and $3.88 \%$, respectively, for 3 -way) compared with HF (4.52 and 3.72\%), resulting in similar MSo yield for JEX and HF (469 and $460 \mathrm{~kg} / \mathrm{cow}$ ) and slightly lower MSo yield for 3-way (453 kg/cow) compared with JEX. As parity increased, milk and MSo yield per cow increased. Reproductive performance was not significantly different between the 3 genotypes, which had similar 24-d submission rates, 6-wk pregnancy rates, and overall pregnancy rates over the 4 -yr period. No difference in calving difficulty, incidence of mastitis, or incidence of lameness was observed among the 3 genotypes. Body weight was significantly different among all 3 genotypes, with HF being the heaviest followed by 3 -way and JEX (530, 499, and $478 \mathrm{~kg}$, respectively), and
\end{abstract}

Received August 20, 2019.

Accepted February 3, 2020.

*Corresponding author: brian.mccarthy@teagasc.ie 3-way cows had a higher body condition score throughout lactation compared with HF and JEX cows. The differences in BW coupled with similar MSo production resulted in JEX cows having the highest production efficiency (4.58 kg of MSo/ $\mathrm{kg}$ of metabolic BW), 3-way cows being intermediate $(4.30 \mathrm{~kg}$ of $\mathrm{MSo} / \mathrm{kg}$ of metabolic BW), and HF cows having the lowest (4.16 kg of $\mathrm{MSo} / \mathrm{kg}$ of metabolic BW). In conclusion, HF herds with poor reproductive performance and low milk fat and protein contents are likely to benefit considerably from crossbreeding with Jersey, and all herds are likely to benefit in terms of production efficiency. However, where herd performance, particularly in relation to reproductive performance, is comparable with $\mathrm{HF}$ in the current study, crossbreeding with Jersey or Norwegian Red is unlikely to lead to significant improvements in overall herd performance.

Key words: genotype, crossbreeding, milk production, reproductive performance

\section{INTRODUCTION}

In Ireland, spring-calving, pasture-based dairy production systems predominate, and $90 \%$ of dairy cows are Holstein-Friesian (HF; DAFM, 2018). Pasturebased dairy systems require compact calving in spring (achieved by attaining high pregnancy rates within a short interval after the start of the breeding season; Berry et al., 2013) and robust animals (Friggens et al., 2017) to produce milk efficiently from pasture (Shalloo et al., 2014).

Considerable evidence exists to demonstrate favorable animal performance benefits from crossbreeding (Buckley et al., 2014) using a range of breeds and across a diversity of production environments (Heins et al., 2006; Prendiville et al., 2011). Delaby et al. (2018) postulated that crossbreeding could provide a better balance to produce robust animals due to a combination of breed complementarity and heterosis. Within 
pasture-based systems both internationally and in Ireland, Jersey has been the predominant breed used to cross with HF. In addition to improvements in milk production traits [i.e., milk fat and protein contents and milk solids (MSo) yield ( $\mathrm{kg}$ of fat + protein)], reproductive performance, and longevity, crossbreeding with Jersey offers advantages relating to intake capacity and production efficiency (Mackle et al., 1996; Prendiville et al., 2009). This combination of characteristics makes the breed particularly suitable for crossbreeding within the context of Ireland's seasonal pasture-based system with a largely export-driven, commodity-based product portfolio; this has been substantiated by Prendiville et al. (2011). Similar results were observed in Northern Ireland and Australia (Auldist et al., 2007; Vance et al., 2013). Crossbreds of Montbéliarde, Normande, and Norwegian Red with HF have also been shown to have superior reproductive performance, with MSo production comparable with that of their HF contemporaries (Heins et al., 2006; Walsh et al., 2007; Begley et al., 2009).

Lopez-Villalobos et al. (2000) hypothesized that a 3 -way rotational crossing system could increase profitability for pasture-based systems in New Zealand. Although the theoretical advantages of a 3-breed rotational crossing system are clear, data to recommend it in practice are very limited. The advantage in theory lies in the maximization of hybrid vigor in later generations compared with a 2 -way reciprocal mating strategy. Recently, 3-way rotational crossing has been shown to improve reproductive performance compared with purebred Holsteins in the United States (Hazel et al., 2014; Shonka-Martin et al., 2019). Ferris et al. (2018) reported similar MSo production and improved functional traits (lower incidences of mastitis and ovarian dysfunction) for a 3-way cross of Swedish-Red $\times$ Jersey/Holstein compared with pure Holstein cows; however, this study comprised only a single lactation.

The objective of this study was to investigate the performance of 3 dairy cow genotypes- HF, Jersey $\times \mathrm{HF}$ $(\mathbf{J E X})$, and Norwegian Red $\times$ JEX cross (3-way) - in terms of milk production, production efficiency, reproductive performance, BW and BCS profiles, and functional traits throughout lactation over a 4-yr period in a pasture-based, spring-calving system. A secondary objective of the study was to investigate the effect of cow parity within each aforementioned genotype for the same production variables.

\section{MATERIALS AND METHODS}

The experiment was conducted at Teagasc Clonakilty Agricultural College $\left(51^{\circ} 63^{\prime} \mathrm{N},-08^{\circ} 85^{\prime} \mathrm{E} ; 25-70 \mathrm{~m}\right.$ above sea level) over 4 yr from 2014 to 2017. A randomized block design was used, with a $2 \times 2$ factorial arrangement of 2 perennial ryegrass (PRG; Lolium perenne L.) ploidies (tetraploid and diploid), each sown with and without white clover (Trifolium repens L.), to give 4 separate grazing treatments as described by McClearn et al. (2019): a tetraploid PRG-only sward, a diploid PRG-only sward, a tetraploid PRG sward with white clover, and a diploid PRG sward with white clover. The grazing area was subdivided into 4 separate farmlets, 1 for each grazing treatment. Each farmlet was stocked at 2.75 cows/ha and comprised 10.9 ha divided into 20 paddocks that were balanced for location, soil type, and soil fertility throughout the farm.

\section{Animals}

As described previously, 3 cow genotypes (HF, JEX, and 3-way) were used for this experiment. HolsteinFriesian cows were mated with either an HF sire to produce an HF cow or a Jersey sire to produce firstgeneration $\left(\mathbf{F}_{\mathbf{1}}\right)$ crossbred JEX cows. The 3 -way cows were produced from $\mathrm{F}_{1}$ JEX cows mated with a Norwegian Red sire. Prior to the current experiment, a parent herd containing HF and JEX cows was bred using the same criteria described above to produce the cows for this study. During the study, each year, a minimum of $3 \mathrm{HF}$, Jersey, and Norwegian Red sires with a high economic breeding index (EBI) were used from the Irish Cattle Breeding Federation (ICBF; Bandon, Co. Cork, Ireland) active bull list, selected from the top 20 bulls within each breed. The EBI is a singlefigure profit index aimed at helping farmers identify the most profitable bulls and cows for breeding dairy herd replacements (Berry et al., 2004, 2005). It now includes 7 subindices related to profitable milk production for pasture-based systems: (1) milk production, (2) fertility, (3) calving performance, (4) beef carcass, (5) cow maintenance, (6) cow management, and (7) health. Every year, 10 cows of each genotype were assigned to 1 of the 4 grazing treatments and balanced for parity (1, 2 , or $3+$ ), calving date, BW, BCS, and $\mathrm{EBI}$, giving a single combined herd of 30 cows per grazing treatment and a total of 40 cows of each genotype in the experiment. Each year, $20 \%$ of the cows in the experiment were primiparous, and the same parity structure was maintained for each grazing treatment and genotype. Four cows were removed during the experiment in 2014, 3 cows were removed in 2015, and 1 cow was removed in 2016 for various reasons (e.g., sickness, death). When a cow was removed, it was replaced by another cow of the same genotype and of similar BW to maintain the stocking rate in that treatment. Neither the cow that 
Table 1. Number of cows of each genotype ${ }^{1}$ each year and lactation records within each genotype during the experiment

\begin{tabular}{lccc}
\hline Item & HF & JEX & 3-way \\
\hline Animals (no.) & 39 & 39 & 38 \\
2014 & 39 & 40 & 38 \\
2015 & 40 & 40 & 39 \\
2016 & 40 & 40 & 40 \\
2017 & & & \\
Lactation records (no.) & 36 & 36 & 35 \\
Parity 1 & 40 & 40 & 40 \\
Parity 2 & 82 & 83 & 80 \\
Parity 3+ &
\end{tabular}

${ }^{1} \mathrm{HF}=$ Holstein-Friesian; JEX $=$ Jersey $\times$ Holstein-Friesian; 3-way $=$ Norwegian Red $\times($ Jersey $\times$ Holstein-Friesian $)$.

was removed nor the replacement cow's data for that lactation were used in the final analysis. Primiparous cows were given an 11-wk dry period, and multiparous cows were given a 9-wk dry period. The decision to dry off cows was based on BCS (cows with BCS $<2.75$ were dried off earlier), level of milk production (i.e., cows producing $<8 \mathrm{~kg}$ of milk/d were dried off), and number of days from calving. Consequently, a total of 472 lactations from 242 spring-calving dairy cows were used $(35,24,24$, and 24 primiparous and $81,93,95$, and 96 pluriparous in 2014, 2015, 2016, and 2017, respectively; Table 1). The EBI of each genotype is shown in Table 2. The EBI and PTA for each cow was calculated as the parental average EBI from the January 2019 ICBF evaluation run. This was to exclude own animal performance, which would have been affected by grazing treatment. The overall EBI differed between genotypes, with $\mathrm{HF}$ at $€ 115$, JEX at $€ 131$, and 3-way at $€ 159$.

\section{Grazing Management}

All 4 grazing treatments were grazed in a springcalving rotational grazing system. Cows were grazed day and night as they calved from February onward as soon as weather conditions allowed and were housed in mid November each year. Cows were supplemented with $4 \mathrm{~kg}$ of concentrate postcalving; this was gradually reduced when grass growth on the grazing treatments exceeded herd demand. Target concentrate supplementation was $350 \mathrm{~kg}$ of $\mathrm{DM} /$ cow per year. During the main grazing season (April to August), when grass growth exceeded herd demand on any grazing treatment, paddocks with surplus herbage were conserved as baled silage. A surplus occurred if grass growth exceeded herd demand, whereas a deficit occurred if grass growth rate was below herd demand (usually in the spring and autumn; Delaby and Horan, 2017). If an herbage deficit occurred across all treatments, then concentrate supplementation was introduced for
Table 2. Mean economic breeding index (EBI), subindices, and PTA for each cow genotype ${ }^{1}$

\begin{tabular}{lccc}
\hline Item & HF & JEX & 3-way \\
\hline EBI $^{2}$ & 115 & 131 & 159 \\
Subindex & & & \\
$\quad$ Milk & 38.7 & 52.1 & 43.4 \\
Fertility & 42.1 & 30.7 & 62.5 \\
Health & 1.5 & 0.7 & 4.0 \\
Calving & 31.6 & 33.6 & 37.2 \\
Beef & -8.9 & -27.6 & -16.7 \\
Maintenance & 8.5 & 36.5 & 25.9 \\
Management & 1.2 & 4.8 & 2.4 \\
PTA (kg) & & & \\
Milk (kg) & 44 & -87.1 & -76 \\
Fat (kg) & 6.8 & 10.5 & 7.8 \\
Protein (kg) & 4.9 & 3.8 & 3.5 \\
Fat (\%) & 0.08 & 0.24 & 0.19 \\
Protein (\%) & 0.06 & 0.12 & 0.11 \\
\hline
\end{tabular}

${ }^{1} \mathrm{HF}=$ Holstein-Friesian; JEX $=$ Jersey $\times$ Holstein-Friesian; 3-way $=$ Norwegian Red $\times($ Jersey $\times$ Holstein-Friesian $)$.

${ }^{2}$ The EBI for each cow was calculated from its parental average EBI taken from the January 2019 Irish Cattle Breeding Federation (Bandon, Cork, Ireland) evaluation run.

all grazing treatments. However, if an herbage deficit occurred in less than all 4 treatments, then the silage produced from that farmlet was used to supplement the deficit to that individual herd. During periods of inclement weather conditions (e.g., excessive rainfall), where grazing conditions were poor, on-off grazing was practiced (Kennedy et al., 2009). Grazing management was achieved by weekly monitoring of average farm cover and using the online application PastureBase to aid in decision making (Hanrahan et al., 2017). Inorganic $\mathrm{N}$ was applied equally across all 4 sward types in the form of urea or calcium ammonium nitrate at a rate of $250 \mathrm{~kg}$ of $\mathrm{N} /$ ha per year.

\section{Grazing Characteristics}

Pregrazing herbage mass was determined before grazing by harvesting 2 strips (approximately $10 \mathrm{~m} \times$ $1.2 \mathrm{~m}$ ) to a height of $4.0 \mathrm{~cm}$ using an Etesia mower (Etesia UK Ltd., Warwick, UK). The harvested forage was weighed and a 100-g subsample was dried at $90^{\circ} \mathrm{C}$ for $15 \mathrm{~h}$ to determine DM. A combined sample from the 2 harvested strips was frozen, freeze-dried, and milled. These samples were analyzed at 4 time points (February/March, mid May/mid June, mid June/mid July, September) and analyzed for ash content, ADF, NDF (Van Soest, 1963), CP (AOAC, 1990), and OM digestibility (Morgan et al., 1989). Postgrazing sward height was measured across whole paddocks after grazing using a rising platemeter (Jenquip, Feilding, New Zealand) to take compressed sward heights at 50 locations. Daily herbage allowance was calculated based on the 
Table 3. Mean grazing characteristics and herbage nutritive values per year across all 4 farmlets

\begin{tabular}{lcccc}
\hline Item & 2014 & 2015 & 2016 & 2017 \\
\hline Pregrazing herbage mass (kg of DM/ha) & 1,753 & 1,637 & 1,586 & 1,538 \\
Herbage allowance (kg of DM/ha per day) & 15.5 & 16.2 & 14.3 & 15.6 \\
Total feed allowance (kg of DM/ha per day) & 17.1 & 17.4 & 16.2 & 17.4 \\
Postgrazing sward height (cm) & 4.13 & 4.19 & 3.99 & 3.81 \\
CP (g/kg) & 218 & 216 & 211 & 199 \\
OM digestibility (g/kg) & 764 & 789 & 781 & 810 \\
NDF (g/kg) & 473 & 393 & 416 & 402 \\
ADF (g/kg) & 270 & 238 & 248 & 236 \\
Ash (g/kg) & 136 & 117 & 111 & 107 \\
\hline
\end{tabular}

residency time within each paddock. Estimated total feed allowance ( $\mathrm{kg}$ of $\mathrm{DM} / \mathrm{cow}$ per day) was calculated by adding daily concentrate and forage supplementation to daily herbage allowance.

Mean grazing characteristics and herbage nutritive values for each year are shown in Table 3. Pregrazing herbage mass was $1,629 \mathrm{~kg}$ of $\mathrm{DM} /$ ha on average over the $4 \mathrm{yr}$, which was above the target of $1,500 \mathrm{~kg}$ of $\mathrm{DM} /$ ha, with some variation among years. Postgrazing sward height was consistently close to the target of 4 $\mathrm{cm}$. Daily herbage allowance and total estimated feed allowance were 15.4 and $17.0 \mathrm{~kg}$ of $\mathrm{DM} /$ cow per day on average over the $4 \mathrm{yr}$. Nutritive value of the swards over the $4 \mathrm{yr}$ was excellent, with an average $\mathrm{CP}$ content of $211 \mathrm{~g} / \mathrm{kg}$, OM digestibility content of $786 \mathrm{~g} / \mathrm{kg}$, and NDF content of $421 \mathrm{~g} / \mathrm{kg}$.

\section{Animal Measurements}

Milk yield was recorded for each cow at every morning $(0700 \mathrm{~h})$ and evening (1530 h) milking, and weekly milk production was derived by summing the individual milk yields for a 7 -d period (Monday to Sunday) and dividing by 7 (Dairymaster, Causeway, Co. Kerry, Ireland). Milk fat, protein, and lactose contents were determined weekly from a consecutive evening and morning milking sample for each cow and were tested using infrared spectrophotometry (Milkoscan 203 DK3400, Foss Electric, Hillerød, Denmark). Milk fat, protein, and lactose yields were calculated by multiplying the weekly milk yield by the weekly milk fat, protein, and lactose contents. Solids-corrected milk (SCM; Tyrrell and Reid, 1965) and MSo yield per cow were also calculated using the weekly milk yields and weekly milk fat and protein contents. Somatic cell count was determined by testing the morning sample from each weekly milk recording using infrared spectrophotometry (Milkoscan 203 DK-3400, Foss Electric). A mean $\mathrm{SCC}$ was calculated for each cow in each year of the experiment by calculating the geometric mean of the SCC for each cow. Total milk, SCM MSo, fat, protein, and lactose yields were calculated by summing the weekly milk yields for each individual cow. Milk solids production per kilogram of metabolic BW (metabolic BW = $\mathrm{BW}^{0.75}$ ) was calculated by dividing total kilograms of MSo per cow per lactation by average metabolic BW. Cows were weighed every 2 wk during lactation upon exit from the milking parlor using an electronic scale (Tru-Test Ltd., Auckland, New Zealand). Body condition score was assessed by the same individual every 2 wk throughout the study on a scale of 1 to 5 in increments of $0.25(1=$ emaciated and $5=$ extremely fat $)$ as outlined by Edmonson et al. (1989). Calving difficulty was recorded for each cow at calving and was ranked on a scale of 1 to $4(1=$ no assistance, $2=$ a small amount of handling, $3=$ mechanical assistance, and 4 $=$ veterinary assistance) and is reported as calving difficulty (where the cow was assigned a calving difficulty score of 2,3 , or 4 at a calving) and calving difficulty $3+$ (the cow was assigned a calving difficulty score of 3 or 4 at calving) for the purpose of analysis. Lameness and mastitis were recorded at every event where a cow required treatment. Lameness was diagnosed by the farm manager and was recorded when treatment was required (i.e., hoof trimming or antibiotics). Lameness incidence is reported as the percentage of cows with at least 1 incidence of lameness in the year. Mastitis was diagnosed by farm personnel using the California Mastitis Test and where antibiotic treatment was required. Mastitis is reported as the percentage of cows with at least 1 case of mastitis per year.

\section{Reproductive Management}

Cows were visually observed for estrus during the breeding season (12-wk period), and breeding commenced between April 20 and 25 each year. Tail paint was used as a heat detection aid, and AI was used for the first 6 wk by the same professional inseminator followed by natural mating using bulls. All cows were inseminated with thawed, frozen semen, the quality (i.e., progressive motility $\geq 60 \%$, morphology $\geq 70 \%$ 
normal, and concentration of the sperm in the semen $\geq 50 \times 10^{6}$ ) of which had been verified before the start of the breeding season. No synchronization of cows occurred over the 4 yr. Transrectal ultrasound imaging was used approximately 30 to 36 and 60 to $66 \mathrm{~d}$ post-AI to determine pregnancy status and to determine overall pregnancy rates at $150 \mathrm{~d}$ after the beginning of the breeding season. The reproductive measurements used were mean calving date, 24-d submission rate (calculated based on animals served within the first $24 \mathrm{~d}$ of the breeding season, irrespective of calving date), calving to first service (interval in days from calving to first service), breeding start date to first service (interval in days from breeding start date to first service), calving to conception interval (interval in days from calving to conception), pregnancy rate to first service (pregnant to first service at the end of the breeding season; does not include cows that conceived to first service but subsequently lost that pregnancy), 6-wk pregnancy rate (pregnant at 6 wk of breeding season and pregnant at the end of the breeding season), embryo mortality (ultrasound scan: pregnant at d 30 post-AI but not pregnant at d 60 post-AI), and overall pregnancy rate. Bulls were chosen with a calving difficulty of less than $5 \%$ for mature cows and less than $2.5 \%$ for heifers. Over the 4 -yr period, the 3 genotypes were mated to a total of 40 bulls, of which 22 were HF, 8 were Jersey, 7 were Norwegian Red, and 3 were beef breeds. Beef sires were used on cows that were considered unsuitable for breeding replacements from due to production or health issues. From 2014 to 2016, 50\% of HF cows were inseminated with $\mathrm{HF}$ straws and $50 \%$ were inseminated with Jersey straws. All JEX $\mathrm{F}_{1}$ cows were inseminated with Norwegian Red straws, and all 3-way cows received HF straws.

\section{Statistical Analysis}

Milk Production. Animal variables such as daily milk yield, fat, protein, and lactose contents, daily MSo, cumulative milk and MSo yield, SCM, kilograms of MSo per kilogram of BW, BW, and BCS were analyzed using PROC MIXED (SAS Institute Inc., Cary, NC), taking into account the effects of genotype, parity, year, grazing treatment, and their subsequent interactions (genotype $\times$ parity, genotype $\times$ year, and genotype $\times$ grazing treatment). Individual cow was the experimental unit. Lactation length was included as a covariate in the model for each respective analysis. Tukey's test was used to determine differences between treatment means. Significance was declared at $P<0.05$.

Reproductive Performance. Calving date, calving to first service interval, breeding start date to first ser- vice, and calving to conception interval were analyzed using PROC MIXED (SAS Institute Inc.), taking into account the effects of genotype, year, parity, grazing treatment, and their subsequent interactions (genotype $\times$ parity, genotype $\times$ year, and genotype $\times$ grazing treatment). Individual cow was the experimental unit. A logistic regression model (PROC LOGISTIC, SAS Institute Inc.) that included the effects of genotype, year, parity, and grazing treatment was used to determine 24-d submission rate, pregnancy rate to first service, 6-wk pregnancy rate, embryo mortality, and overall pregnancy rate.

$B W, B C S$, and Functional Traits. Body weight, BCS (mean during lactation, at calving, and at drying off), and SCC were analyzed using PROC MIXED (SAS Institute Inc.), taking into account the effects of genotype, year, parity, grazing treatment, and their subsequent interactions (genotype $\times$ parity, genotype $\times$ year, genotype $\times$ grazing treatment). Individual cow was the experimental unit. A logistic regression model (PROC LOGISTIC, SAS Institute Inc.) that included the effects of genotype, parity, and grazing treatment was used to determine calving difficulty, lameness incidence, and mastitis incidence.

\section{RESULTS}

\section{Genotype Responses}

Milk Production. The effect of cow genotype on milk production is presented in Table 4. Milk yield variables differed each year with the exception of fat content (data not shown). Significant differences among genotypes were observed for all variables with the exception of total protein yield across lactation $(P>0.05)$. Lactation length varied among genotypes: JEX had a longer lactation length of $285 \mathrm{~d}$ compared with 3-way ( $280 \mathrm{~d}, P=0.031)$ and $\operatorname{HF}(283 \mathrm{~d})$ due to JEX having an earlier mean calving date. Daily milk yield per cow was significantly higher for HF compared with the 2 crossbreds, which had similar daily yields $(19.7,18.9$, and $18.5 \mathrm{~kg} /$ cow per day for HF, JEX, and 3 -way, respectively; Figure 1). Total milk yield per cow was significantly higher for HF compared with the 2 crossbreds, which were similar (Table 4). The JEX and 3 -way cows had similar fat and protein contents, which were significantly higher than $\operatorname{HF}(P<0.001)$. Total fat yield was highest for JEX, with HF and 3-way having similar total fat yields $(261,252$, and $250 \mathrm{~kg} / \mathrm{cow}$ for JEX, HF, and 3-way, respectively). Daily MSo yield was greater for JEX than for 3-way (1.59 vs. $1.55 \mathrm{~kg} /$ cow per day), whereas HF (1.56 kg of MSo/cow per day) was not different from either of the crossbreds 
Table 4. Effect of cow genotype on milk production per cow variables

\begin{tabular}{|c|c|c|c|c|c|}
\hline Item & \multicolumn{3}{|c|}{ Genotype $^{1}$} & SE & $P$-value \\
\hline Lactation length (d) & $283^{\mathrm{ab}}$ & $285^{\mathrm{a}}$ & $280^{\mathrm{b}}$ & 1.4 & 0.032 \\
\hline Total solids-corrected milk (kg/cow) & $5,827^{\mathrm{a}}$ & $5,905^{\mathrm{a}}$ & $5,681^{\mathrm{b}}$ & 41.3 & $<0.001$ \\
\hline Fat content $(\%)$ & $4.52^{\mathrm{a}}$ & $4.86^{\mathrm{b}}$ & $4.75^{\mathrm{b}}$ & 0.038 & $<0.001$ \\
\hline Protein content $(\%)$ & $3.72^{\mathrm{a}}$ & $3.87^{\mathrm{b}}$ & $3.88^{\mathrm{b}}$ & 0.017 & $<0.001$ \\
\hline Total protein yield ( $\mathrm{kg} / \mathrm{cow})$ & 208 & 208 & 204 & 1.5 & 0.068 \\
\hline Total lactose yield (kg/cow) & $273^{\mathrm{a}}$ & $266^{\mathrm{b}}$ & $256^{\mathrm{c}}$ & 2.3 & $<0.001$ \\
\hline Total $\mathrm{MSo}^{2}$ yield $(\mathrm{kg} / \mathrm{cow})$ & $460^{\mathrm{ab}}$ & $469^{\mathrm{a}}$ & $453^{\mathrm{b}}$ & 3.3 & 0.004 \\
\hline Total MSo yield/BW ( $\mathrm{kg}$ of MSo/ $\mathrm{kg}$ of metabolic $\mathrm{BW}^{3}$ ) & $4.16^{\mathrm{a}}$ & $4.58^{\mathrm{b}}$ & $4.30^{\mathrm{c}}$ & 0.03 & $<0.001$ \\
\hline
\end{tabular}

${ }^{a-c}$ Means within a row with different superscripts are significantly different $(P<0.05)$.

${ }^{1} \mathrm{HF}=$ Holstein-Friesian; JEX $=$ Jersey $\times$ Holstein-Friesian; 3-way $=$ Norwegian Red $\times($ Jersey $\times$ Holstein-Friesian $)$.

${ }^{2}$ Total milk solids $(\mathrm{MSo})=\mathrm{kg}$ of fat + protein.

${ }^{3}$ Metabolic BW $=\mathrm{BW}^{0.75}$.

(Figure 2). Total MSo yield was influenced by genotype: JEX and HF had similar total MSo yield (469 and $460 \mathrm{~kg} /$ cow, respectively), and JEX had significantly higher MSo compared with 3-way (453 kg/cow). Total MSo yield was also similar between $\mathrm{HF}$ and 3-way. The most efficient genotype in terms of MSo per kilogram of metabolic BW was JEX, followed by 3 -way and then HF $(P<0.001)$.

Reproductive Performance. Grazing treatment did not affect animal reproductive performance or func- tional traits and is reported in a separate publication (McClearn et al., 2019). The reproductive performance of the 3 genotypes is shown in Table 5 , with only 2 parameters showing a significant difference between genotypes. Calving date was significantly affected by genotype, with JEX having an earlier mean calving date compared with HF and 3-way (Feb. 2 vs. Feb. 6 and 7 , respectively; $P=0.003$ ). The variation in calving date subsequently led to a difference among genotypes for calving to service interval. Calving to service

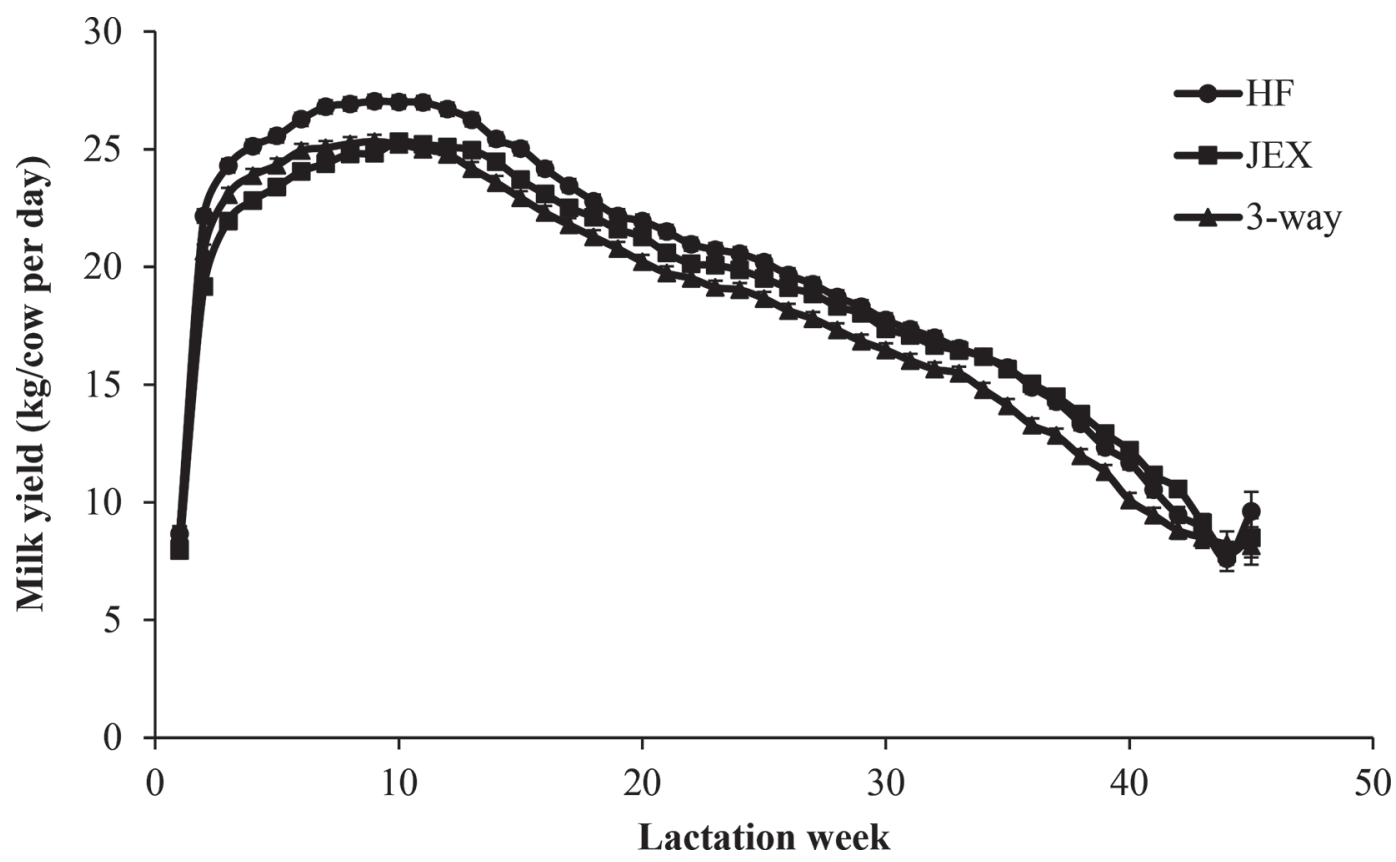

Figure 1. Four-year mean comparison of the daily milk yield of Holstein-Friesian (HF) cows with that of Jersey $\times$ HF $($ JEX) and Norwegian Red $\times($ Jersey $\times$ HF; 3-way) crossbred cows from 2014 to 2017. Error bars represent SE of daily milk yield. 


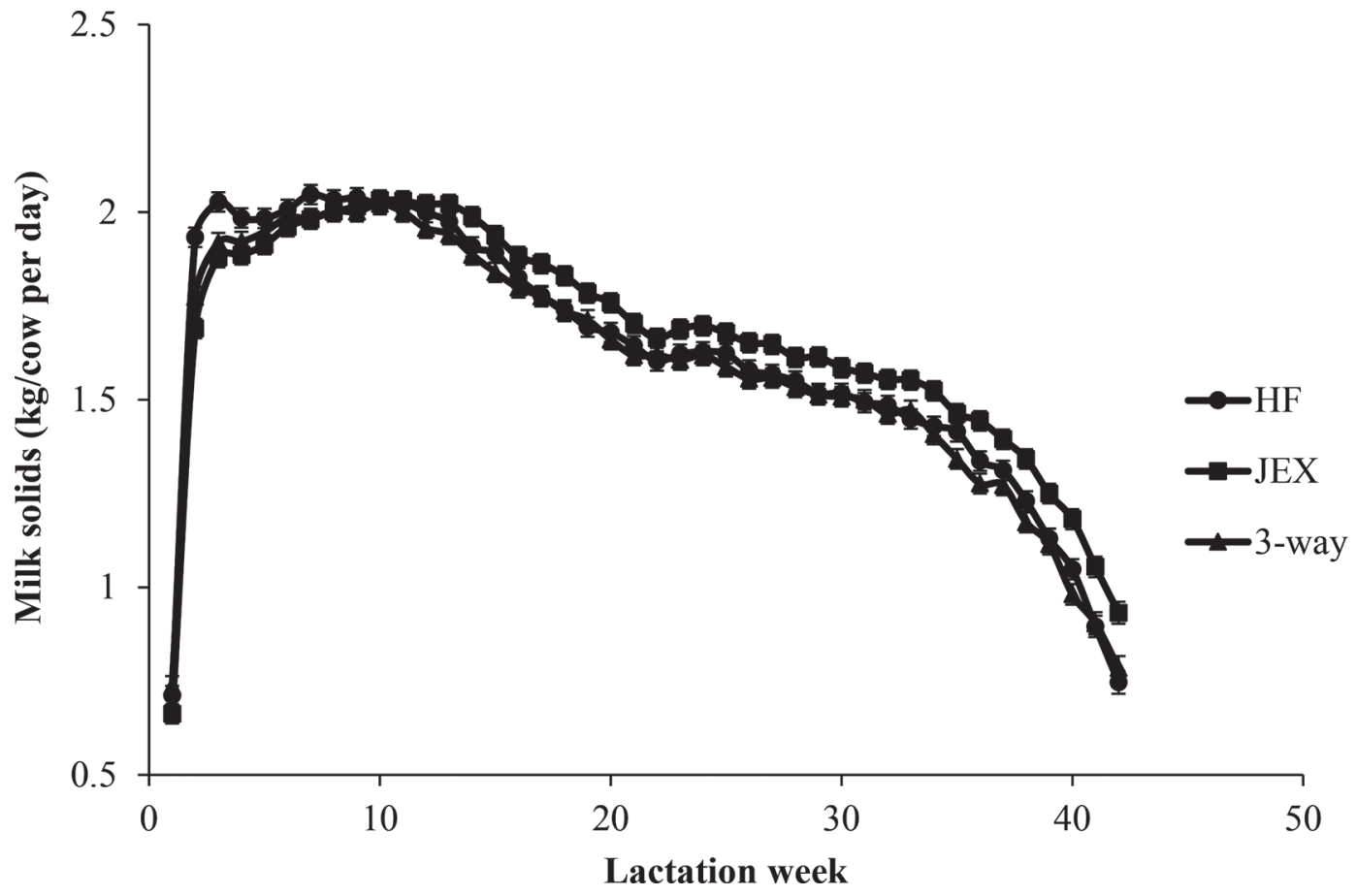

Figure 2. Four-year mean comparison of the daily milk solids yield of Holstein-Friesian (HF) cows with that of Jersey $\times$ HF $($ JEX) and Norwegian Red $\times$ (Jersey $\times$ HF; 3-way) crossbred cows from 2014 to 2017 . Error bars represent SE of daily milk solids yield.

interval was longer for JEX than for HF and 3-way (91 vs. 85 and 84 d, respectively). Calving to conception interval, breeding start date to first service, $24-\mathrm{d}$ submission rate, pregnancy rate to first service, 6 -wk pregnancy rate, overall pregnancy rate, and embryo mortality were similar for all genotypes over the 4-yr period $(P>0.05)$.

$B W, B C S$, and Functional Traits. Body weight was significantly different among the 3 genotypes on average throughout lactation and at calving (Table 6; $P<0.001)$. Holstein-Friesian cows had a consistently higher BW on average: they were $31 \mathrm{~kg}$ heavier than 3 -way cows and $52 \mathrm{~kg}$ heavier than JEX cows (Table 6 ; Figure 3). Body weight also differed for parity, with parity 1 cows having the lowest BW, followed by parity 2 and $3+$ cows $(P<0.001$; Table 7$)$. Body condition score also differed among genotypes, with HF and JEX having similar BCS on average over the 4 yr but 3 -way

Table 5. Effect of cow genotype on reproductive performance from 2014 to 2017

\begin{tabular}{|c|c|c|c|c|c|}
\hline \multirow[b]{2}{*}{ Item } & \multicolumn{3}{|c|}{ Genotype $^{1}$} & \multirow[b]{2}{*}{ SE } & \multirow[b]{2}{*}{$P$-value } \\
\hline & $\mathrm{HF}$ & JEX & 3-way & & \\
\hline Calving date & Feb. $6^{\text {a }}$ & Feb. $2^{\mathrm{b}}$ & Feb. $7^{\mathrm{a}}$ & 1.12 & 0.007 \\
\hline Calving to service interval (d) & $85^{\mathrm{a}}$ & $91^{\mathrm{b}}$ & $84^{\mathrm{a}}$ & 1.25 & $<0.001$ \\
\hline Breeding start to first service interval (d) & 9.5 & 11.3 & 9.9 & 0.64 & 0.102 \\
\hline Calving to conception interval (d) & 94 & 95 & 93 & 1.76 & 0.497 \\
\hline 24 -d submission rate $(\%)$ & 97.5 & 93.1 & 97.5 & - & 0.999 \\
\hline Pregnancy rate to first service $^{2}(\%)$ & 65.2 & 73.0 & 65.6 & - & 0.242 \\
\hline 6 -wk pregnancy rate $(\%)$ & 88.0 & 87.4 & 84.1 & - & 0.362 \\
\hline Overall 12 -wk pregnancy rate $(\%)$ & 96.8 & 93.1 & 93.0 & - & 0.966 \\
\hline Embryo mortality (\%) & 2.53 & 2.52 & 3.18 & - & 0.999 \\
\hline
\end{tabular}

$\overline{\mathrm{a}, \mathrm{b}}$ Means within a row with different superscripts are significantly different $(P<0.05)$.

${ }^{1} \mathrm{HF}=$ Holstein-Friesian; JEX $=$ Jersey $\times$ Holstein-Friesian; 3-way $=$ Norwegian Red $\times($ Jersey $\times$ HolsteinFriesian).

${ }^{2}$ Pregnancy rate to first service at the end of the breeding season; does not include cows that conceived to first service but subsequently lost that pregnancy. 
Table 6. Effect of cow genotype on BW, BCS, and health performance

\begin{tabular}{|c|c|c|c|c|c|}
\hline \multirow[b]{2}{*}{ Item } & \multicolumn{3}{|c|}{ Genotype $^{1}$} & \multirow[b]{2}{*}{$\mathrm{SE}$} & \multirow[b]{2}{*}{$P$-value } \\
\hline & $\mathrm{HF}$ & JEX & 3-way & & \\
\hline Average BW (kg/cow) & $530^{\mathrm{a}}$ & $478^{\mathrm{b}}$ & $499^{c}$ & 3.4 & $<0.001$ \\
\hline BW at calving (kg/cow) & $542^{\mathrm{a}}$ & $493^{\mathrm{b}}$ & $515^{\mathrm{c}}$ & 5.0 & $<0.001$ \\
\hline BW at dry off ( $\mathrm{kg} / \mathrm{cow})$ & $572^{\mathrm{a}}$ & $515^{\mathrm{b}}$ & $540^{\mathrm{c}}$ & 4.0 & $<0.001$ \\
\hline Average BCS $^{2}$ & $2.93^{\mathrm{a}}$ & $2.94^{\mathrm{a}}$ & $2.99^{\mathrm{b}}$ & 0.011 & $<0.001$ \\
\hline BCS at calving & $3.14^{\mathrm{a}}$ & $3.14^{\mathrm{a}}$ & $3.20^{\mathrm{b}}$ & 0.016 & 0.008 \\
\hline BCS at dry off & $2.85^{\mathrm{a}}$ & $2.83^{\mathrm{a}}$ & $2.92^{\mathrm{b}}$ & 0.017 & $<0.001$ \\
\hline Calving difficulty ${ }^{3}(\%)$ & 26.6 & 30.2 & 25.5 & - & 0.529 \\
\hline Calving difficulty $3+4(\%)$ & 7.0 & 5.0 & 4.5 & - & 0.596 \\
\hline Lameness (\%) & 18.4 & 13.8 & 15.3 & - & 0.439 \\
\hline Mastitis (\%) & 5.1 & 6.9 & 7.6 & - & 0.906 \\
\hline $\mathrm{SCC}($ cells $/ \mathrm{mL})$ & 50.2 & 46.5 & 43.5 & 3.76 & 0.450 \\
\hline
\end{tabular}

${ }^{\mathrm{a}-\mathrm{c}}$ Means within row with different superscripts are significantly different $(P<0.05)$.

${ }^{1} \mathrm{HF}=$ Holstein-Friesian; JEX $=$ Jersey $\times$ Holstein-Friesian; 3 -way $=$ Norwegian Red $\times($ Jersey $\times$ HolsteinFriesian).

${ }^{2}$ Body condition was scored by the same individual every 2 wk throughout the study on a scale of 1 to 5 in increments of 0.25 ( 1 = emaciated and $5=$ extremely fat $)$ as outlined by Edmonson et al. (1989).

${ }^{3}$ Calving difficulty $=$ cows assigned 2,3 , or 4 on calving difficulty scale where $2=$ a small amount of handling, $3=$ mechanical assistance and, $4=$ veterinary assistance.

${ }^{4}$ Calving difficulty $3+=$ cows assigned 3 or 4 on calving difficulty scale where $3=$ mechanical assistance, and $4=$ veterinary assistance.

cows having consistently higher BCS (Figure 4). The higher BCS in 3-way cows was recorded from calving and carried on throughout lactation until drying off. Higher BCS was also observed with greater-parity animals, as parity $3+$ animals had significantly higher BCS compared with parity 1 and 2 animals (Table 7 ). Functional performance of the cows was recorded using 4 parameters: calving difficulty (scale of 1 to 4 ), lameness incidence (\%), mastitis incidence (\%), and SCC. There was no significant effect of genotype on any of the functional traits analyzed (Table 6).

\section{Effect of Parity}

Parity differences caused a significant response $(P$ $<0.001)$ in all milk yield variables analyzed with the exception of milk fat content (Table 7). Milk and MSo yield increased with greater parity $(4,822,5,631$, and $6,105 \mathrm{~kg}$ of milk/cow and 400,468, and $513 \mathrm{~kg}$ of MSo/ cow for parity 1,2 , and $3+$ cows, respectively). There was an interaction between genotype and parity $(P=$ 0.003 ) for milk yield per cow, as milk yield per cow was similar for all 3 genotypes in parity 1 but significantly higher for HF than JEX and 3-way in parity 2 and 3+. Similar trends in fat content were observed for each genotype from parity 1 to $3+$, with no genotype $\times$ parity interaction observed. Protein content for each genotype increased linearly with parity. Milk solids production was affected by parity, with total MSo yield increasing with parity, but no interaction between parity and genotype for MSo yield was observed. Parity had no effect on 6-wk pregnancy rate or overall pregnancy rate, and there was no interaction between genotype and parity for the reproductive variables reported. First-parity animals had a greater mean SCC (63 cells/ $\mathrm{mL}$ ) than parity 2 and $3+$ animals ( 35 and 42 cells $/ \mathrm{mL}$, respectively); however, this did not increase incidence of mastitis (data not shown). Lameness incidence increased $(P<0.001)$ as parity increased.

\section{DISCUSSION}

The trend for crossbred cows has been influenced by expanding herds and larger herd sizes, with a demand for "easy care" or robust animals that suit reduced labor input systems and, in particular, pasture-based systems (Sørensen, 2007; Veerkamp et al., 2013). However, the use of crossbreeding in spring-calving systems has been limited in Ireland, with only $5.2 \%$ of herds reported as crossbred in 2014 (Department of Agriculture, 2014).

\section{Milk Production}

The sward performance is reported in Table 3 and confirms that all animals were provided with high-quality herbage. Therefore, the expression of performance differences between cow genotypes should not have been influenced by herbage allowance or nutritive value of the swards. Total milk yield differences between genotypes (HF milk yield was 4.2 and $6.2 \%$ higher than JEX and 3-way, respectively) are in agreement with multiple previous studies comparing HF and JEX cows 
(Prendiville et al., 2010; Vance et al., 2012; Coffey et al., 2017). This is due to the higher genetic merit for milk yield (i.e., milk kilograms; Table 2) for HF compared with JEX and 3-way. However, MSo production of $\mathrm{HF}$ and JEX cows in our study was similar, which is in agreement with Vance et al. (2012) but in contrast with several studies that reported increased MSo yield from JEX cows (Prendiville et al., 2011; Coffey et al., 2016, 2017). The similar milk solids yield per cow was due to the significantly higher fat and protein contents of JEX milk compared with HF milk (White, 2001). The JEX cows had greater MSo than 3-way cows due to the numerically higher total milk yield and fat content of JEX cows. Limited studies have compared 3-way crosses, as used in this study, with HF and JEX. Hazel at al. (2014) compared purebred Holsteins, Holstein $\times$ Montbéliarde, and a 3-breed crossbred of Montbéliarde $\times$ Jersey $\times$ Holstein and found no significant difference in total MSo yield among all 3 breeds. Ferris et al. (2018) compared the production of purebred Holsteins with Swedish Red $\times$ Jersey $\times$ Holstein cows in pasturebased systems. They found that purebred Holsteins had significantly higher total milk yields compared with the crossbreds but similar total MSo yields. The results of the current study corroborate previous research in demonstrating the ability of Jersey and Norwegian Red crossbred cows to produce similar or greater amounts of MSo compared with purebred HF from a lower milk volume in pasture-based production systems with low levels of external supplement use.
Crossbred animals can offer benefits in terms of milk production efficiency, with JEX and 3-way producing 4.58 and $4.30 \mathrm{~kg}$ of $\mathrm{MSo} / \mathrm{kg}$ of $\mathrm{BW}^{0.75}$, respectively, over the entire lactation, which is a 10.1 and $3.36 \%$ increase, respectively, compared with $\mathrm{HF}$ (4.16 $\mathrm{kg}$ of $\mathrm{MSo} / \mathrm{kg}$ of $\left.\mathrm{BW}^{0.75}\right)$. The $10.1 \%$ increase in MSo per kilogram of metabolic BW is similar to the $14 \%$ increase in MSo per $100 \mathrm{~kg}$ of BW observed by Coffey et al. (2017) for JEX compared with HF cows. Previous studies have attributed the differences in production efficiency to differences in BW, grazing behavior (Prendiville et al., 2010; Vance et al., 2012), and gastrointestinal tract weight (Beecher et al., 2014) specifically associated with the Jersey breed. The intake capacity of Jersey animals is greater than that of other breeds in relation to total BW (Mackle et al., 1996). Prendiville et al. (2009) reported greater DMI per $100 \mathrm{~kg}$ of $\mathrm{BW}$ for $\mathrm{F}_{1}$ JEX compared with HF (3.63 vs. $3.39 \mathrm{~kg} / 100 \mathrm{~kg}$ of BW) in a pasture-based system, which affects production efficiencies in terms of BW in favor of Jersey and Jersey crossbred animals (Heins et al., 2008). It is notable that in this experiment the gains in efficiency were not as great for the 3-way cows as they were for the JEX cows due to their higher BW and reduced MSo. Further investigation of the production efficiencies in terms of BW, maintenance, and DMI is required because few, if any, studies have investigated these efficiencies in 3-way cows.

The observation that parity 2 and $3+$ cows produced 16.9 and $26.6 \%$ greater milk yield, respectively, than

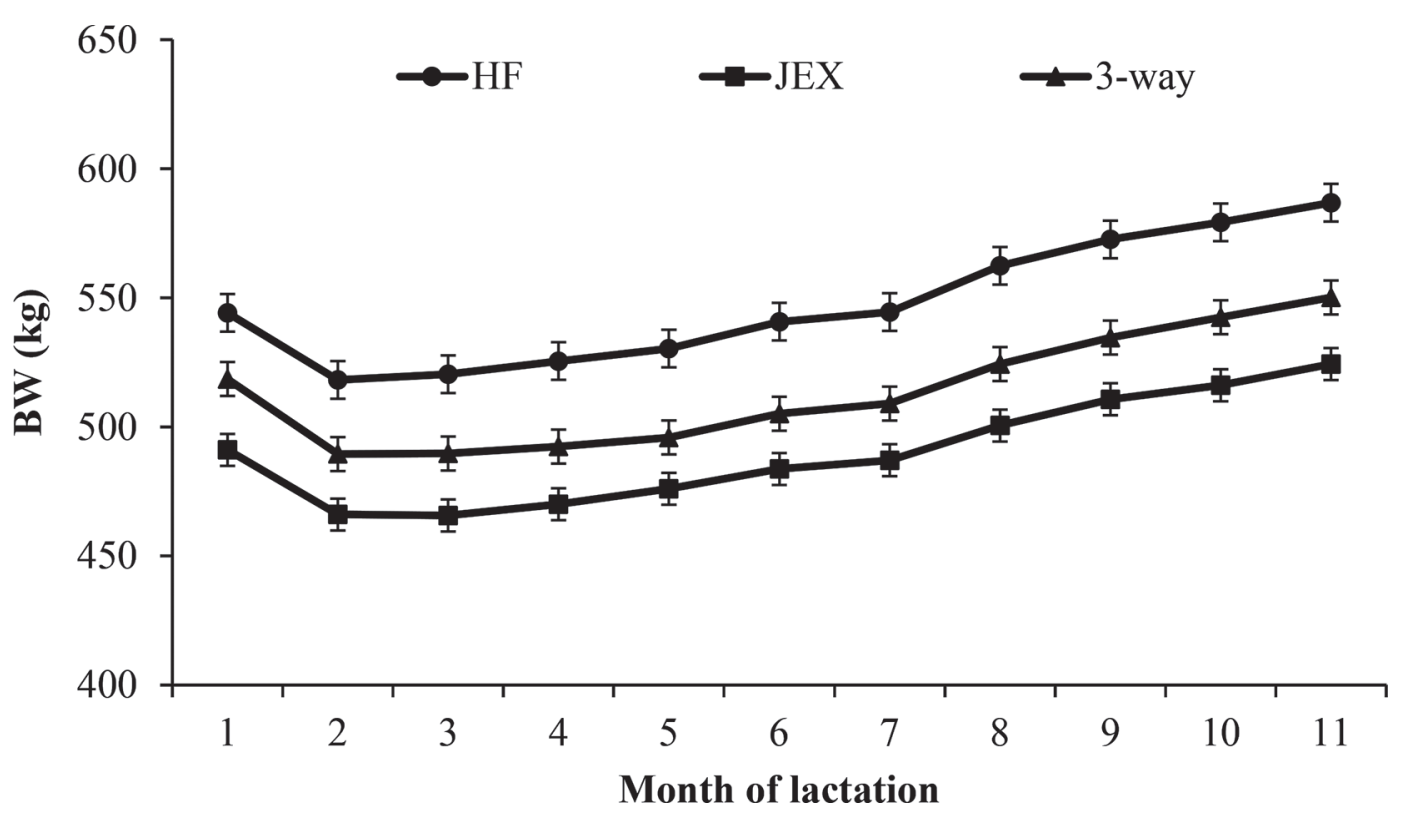

Figure 3. Four-year mean comparison of the BW of Holstein-Friesian $(\mathrm{HF})$ cows with that of Jersey $\times$ HF $($ JEX) and Norwegian Red $\times$ (Jersey $\times$ HF; 3 -way) crossbred cows for every 4 wk of lactation (e.g., $1=$ first 4 wk of lactation, $2=$ second 4 wk of lactation) from 2014 to 2017. Error bars represent SE of 4-wk BW. 


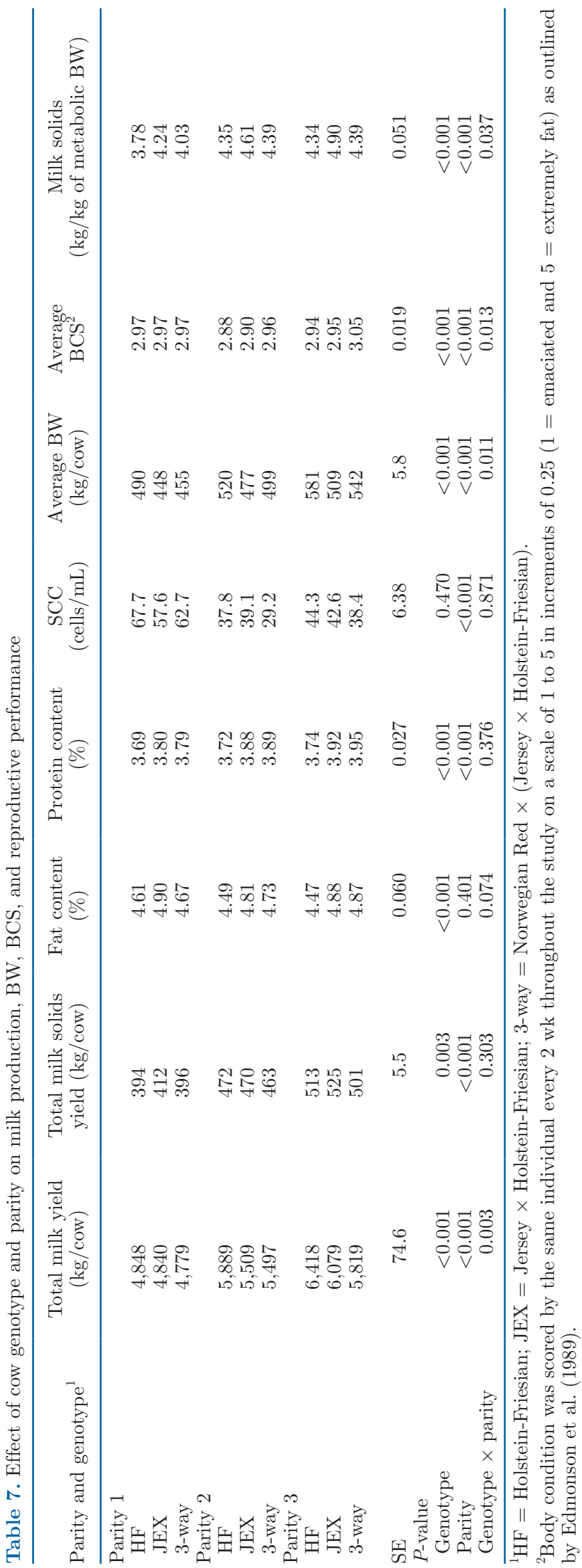

parity 1 cows is in agreement with Berry (2015), who reported similar differences of 16 to $19 \%$ and 28 to $31 \%$, respectively. These differences can be attributed to the greater peak in milk production associated with higher parity animals (Horan et al., 2005). We believe it is useful to provide results on the different parities, particularly first-parity animals, which are often omitted in systems experiments. The interaction between parity and genotype for milk yield is due to the similar milk yield of all genotypes in parity 1 (range in milk yield for parity 1 animals was $69 \mathrm{~kg} / \mathrm{cow}$ ), whereas there were significant differences in milk yield among genotypes for parity 2 and $3+$ animals (range in milk yield for parity 2 and $3+$ animals was 392 and $599 \mathrm{~kg} /$ cow, respectively). Total MSo yield increased as parity increased, and total MSo yield was significantly higher in parity 1 for JEX cows compared with HF and 3-way cows. However, in agreement with several studies, there was no interaction between genotype and parity for MSo yield (Vance et al., 2012; Hazel et al., 2014). The parity $\times$ genotype interaction for milk yield per cow could be important because improved performance from parity 1 onward can affect the profitability of an animal over their lifetime, which may also have implications for future genetic evaluations. However, it should be acknowledged that the results observed are from a single study with limited cow numbers, so further investigation into the validity of the parity $\times$ genotype interaction is required.

\section{Reproductive Performance}

In spring-calving, pasture-based systems, a herd's reproductive performance is critical because cows must calve in a short timeframe in spring to match grass production with herd demand and maximize milk production from pasture (Shalloo et al., 2014). It is therefore an important observation of the current study that the reproductive performance of all 3 genotypes was excellent. Similar results were observed for key performance indicators of spring-calving, pasture-based herds, such as 6 -wk pregnancy rate and overall pregnancy rate (on average 86.3 and $94.3 \%$, respectively, in this study).

Numerous studies have reported $\mathrm{F}_{1}$ JEX cows to have superior reproductive performance in seasonal, pasturebased systems compared with HF cows. Vance et al. (2013) and Prendiville et al. (2011) reported higher submission rates, pregnancy rates to first and second service, 6-wk pregnancy rate, and overall pregnancy rate in $\mathrm{F}_{1}$ JEX cows compared with $\mathrm{HF}$ cows across different seasonal, pasture-based systems. Although our results are in contrast with these previous studies, our results corroborate more recent research that has shown improvements in the reproductive performance of $\mathrm{HF}$ in 
Ireland (ICBF, 2019a; O'Sullivan et al., 2020). Coffey et al. (2016) compared the reproductive performance of Holstein, Friesian, and Jersey crossbred cows in springcalving commercial dairy farms in Ireland and found an average submission rate of $74 \%$ and a 6 -wk pregnancy rate of $66 \%$ from 2008 to 2012 with no consistent genotype effect noted, although calving interval and age at first calving were significantly lower for crossbred animals compared with both parental averages. In this study, JEX cows had a significantly earlier average mean calving date (Feb. 2) compared with $\mathrm{HF}$ and 3-way cows (Feb. 6 and 7, respectively). This was likely due to their numerically higher pregnancy rate to first service, which, although not statistically significant, was $7.8 \%$ greater for JEX cows compared with HF and 3 -way cows. Leane (2016) reported no significant differences between HF and JEX cows for submission rate, 6 -wk pregnancy rate, or overall pregnancy rate across several pasture-based grazing treatments. Very limited studies have evaluated the effect of 3-way rotational crossing on reproductive performance, and none have examined the combination of breeds used in this study. Hazel et al. (2014) reported a significant difference between purebred Holsteins and Montbéliarde $\times$ Jersey $\times$ Holstein for pregnancy rate to first service, with the latter having a 23\% higher rate and 43 fewer days open. Norwegian Red was chosen as the third breed in the current study due to the findings of Walsh et al.
(2008), who concluded that of the 3 alternative breeds evaluated (Montbéliarde, Normande, and Norwegian Red), the Norwegian Red was most suited to seasonal, pasture-based milk production systems. Although the Norwegian Red produced slightly less milk (solids corrected) compared with $\mathrm{HF}$, the breed displayed many favorable traits - namely, superior reproductive efficiency, superior udder health, and a moderate size. Ferris et al. (2018) reported, over 1 lactation, that Holstein cows had greater ovarian dysfunction than Swedish Red $\times$ Jersey $\times$ Holstein crossbreds; however, overall reproductive performance was not reported.

The EBI differences among genotypes (EBI was higher for both crossbred genotypes compared with HF; Table 2) and the anticipated effect of heterosis was expected to have a positive effect on the reproductive performance of the crossbred cows in this study. The lack of an effect of genotype on reproductive performance may be attributed to excellent reproductive management (the same technician was in charge of reproductive management of the herd for the duration of the experiment), the early mean calving date of the herd, the relatively high average mean BCS of the HF within this study, and the long-term gains in genetic merit for reproductive and functional traits since the introduction of the EBI in 2000 (Berry et al., 2005; ICBF, 2019b; O'Sullivan et al., 2020). It should also be noted that although HF and JEX had lower BCS than

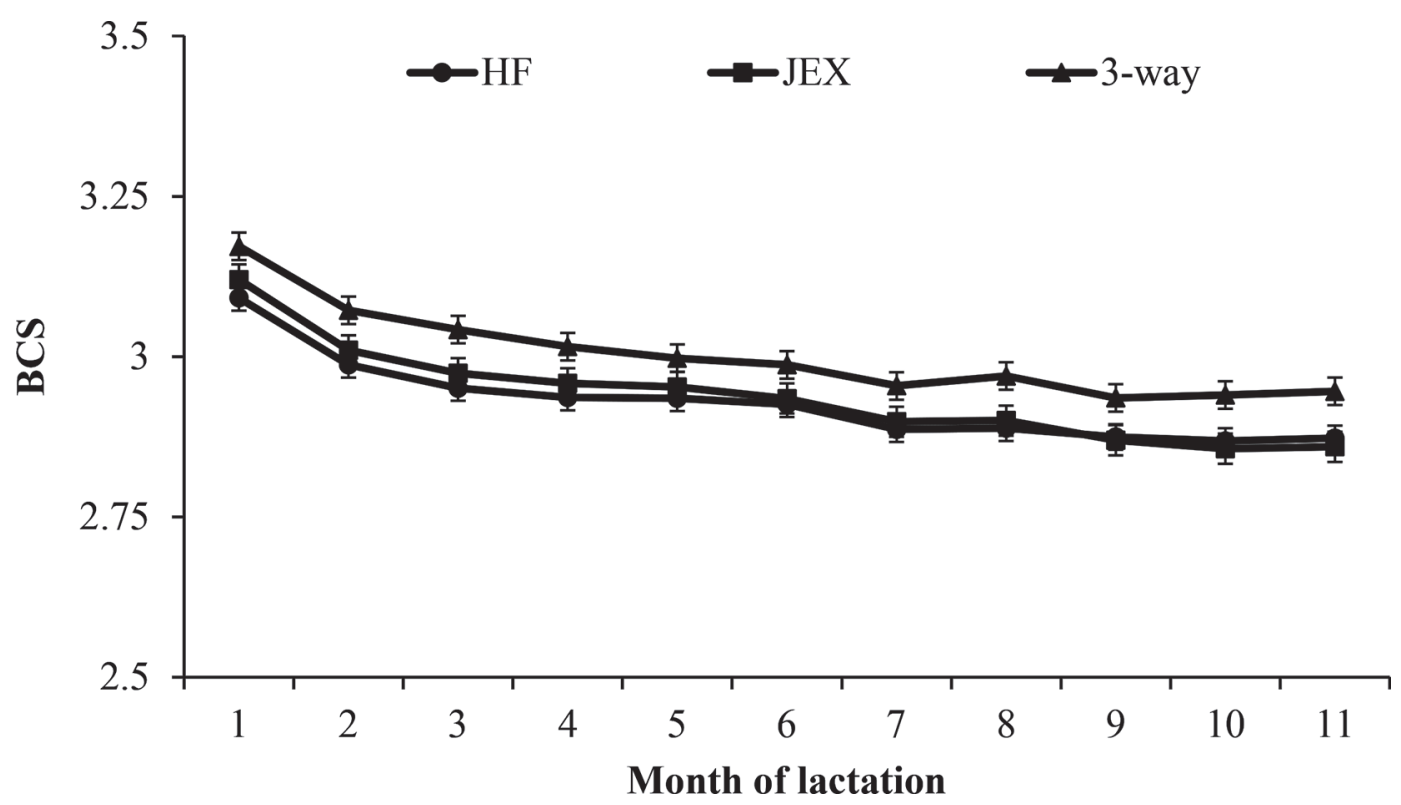

Figure 4. Four-year mean comparison of the BCS of Holstein-Friesian (HF) cows with that of Jersey $\times$ HF $($ JEX) and Norwegian Red $\times$ (Jersey $\times$ HF; 3-way) crossbred cows for every 4 wk of lactation (e.g., $1=$ first 4 wk of lactation, $2=$ second 4 wk of lactation) from 2014 to 2017. Body condition was scored by the same individual every 2 wk throughout the study on a scale of 1 to 5 in increments of $0.25(1=$ emaciated and $5=$ extremely fat) as outlined by Edmonson et al. (1989). Error bars represent SE of 4-wk BCS. 
3-way, their mean BCS during lactation (2.94) was similar to that of the elite cows in the Teagasc "next generation herd" (2.91; O'Sullivan et al., 2019, 2020) compared with the national average of 2.72 . It has been well documented that genetic selection for fertility and health traits in lactating dairy cows results in improved fertility phenotypes (Cummins et al., 2012; Moore et al., 2014; O'Sullivan et al., 2020), and although the genetic merit of the HF cows was lower than that of the JEX and 3-way cows, it was greater than that of the national average cows $(€ 47)$ in the next generation herd (O'Sullivan et al., 2020).

\section{BW, BCS, and Functional Traits}

In this study, crossbreeding HF with Jersey and subsequently with Norwegian Red resulted in lighter cows compared with HF and, in the case of 3-way, cows with higher BCS. Prendiville et al. (2011) reported that HF were heavier but had lower BCS on average over the lactation than $\mathrm{F}_{1}$ JEX. Similarly, Auldist et al. (2007) found BCS in early lactation to be slightly higher for Jersey $\times$ Holstein cows than for Holstein cows, but the changes in BCS between calving and the start of breeding were similar between breed groups. In our study, although the HF cows were $52 \mathrm{~kg}$ heavier than the JEX cows, there was no significant difference in BCS between HF and JEX. The 3-way crossbred used by Ferris et al. (2018) had significantly higher BCS compared with HF, which is supported by the results of our study. The positive effect on BCS that breeds such as Norwegian Red, Swedish Red, and so on contribute to an $\mathrm{F}_{1}$ cross or backcross is evident and is due to the breeding programs of these breeds selecting for improved reproductive and functional traits (Walsh et al., 2008; Shonka-Martin et al., 2019).

There was no effect of genotype on the recorded functional traits (calving difficulty, lameness incidence, mastitis incidence, or SCC), which is in contrast to previous reports that crossbreeding would lead to a more robust, easy-care cow (Buckley et al., 2014). Calving difficulty or dystocia has been defined in the Irish context as a calving event during which the cow needs mechanical intervention or veterinary assistance. A review undertaken in 2008 reported a prevalence of dystocia of $4.1 \%$ in Irish dairy herds, where dams are primarily $\mathrm{HF}$, and a calving difficulty of only $1.5 \%$ in Norway, where the primary dam is Norwegian Red (Mee, 2008). No difference in calving difficulty was observed between the 3 genotypes in this study, and all sires chosen had $<5 \%$ expected calving difficulty. However, as half of the HF cows in this study were bred with Jersey sires, they would have had a low expected calving difficulty; this may have reduced the incidence of calving difficulty for $\mathrm{HF}$.

Lameness is an important health trait in dairy cows that can have a negative effect on animal production and economic performance (Green et al., 2002). Although the JEX and 3-way cows had a numerically lower incidence of lameness in this study compared with HF, it was not significantly different. Previous studies have found similar results with differences in lameness between purebred HF and crossbred cows being insignificant (Bjelland et al., 2011; Vance et al., 2012; Ferris et al., 2018). Studies on the prevalence of lameness in pasture-based systems are limited. However, a recent study undertaken on pasture-based dairy herds in Australia concluded that the average prevalence of lameness was 18.9\% (Ranjbar et al., 2016), which aligns well with the lameness incidences reported in this study. Higher parity animals in this study had increased incidences of lameness, which is in agreement with Pryce et al. (1999), who reported that incidence of disease increased as parity increased. Booth et al. (2004) also predicted a 4-times-higher risk of lameness in parity $3+$ cows compared with parity 1 cows.

Genotype had no effect on the recorded incidences of mastitis in this study, with an average prevalence of $6.5 \%$ across the herd. This is consistent with previous studies in which there was no significant difference in prevalence of mastitis between $\mathrm{HF}$ and crossbred cows (Prendiville et al., 2010; Bjelland et al., 2011). In contrast, Ferris et al. (2018) reported Holstein cows to have significantly higher incidences of mastitis compared with a 3-way breed of Swedish Red $\times$ Jersey $\times$ Holstein ( $26 \%$ vs. $6 \%$, respectively) but found the 3-way breed to have a significantly higher SCC. Similarly, Vance et al. (2012) found HF cows to have significantly higher cases of mastitis compared with Jersey $\times$ HF cows ( $29 \%$ vs. $16 \%$, respectively). However, Vance et al. (2012) reported no difference in SCC between the 2 breeds, similar to Prendiville et al. (2010), who found no difference in SCC between HF, Jersey, and JEX cows. This is in agreement with the modeled benefits of heterosis on SCC, which found small, insignificant differences between purebred and crossbred cows (VanRaden and Sanders, 2003). The lack of a genotype effect is somewhat surprising, particularly for the 3-way cows, as functional and health traits have been selected for in the Norwegian Red breeding program for decades (Walsh et al., 2008). The EBI has a relative emphasis of $4 \%$ on health traits, and the results suggest that this has been sufficient to provide animals with high EBI genetics, regardless of genotype, that are suitable for pasture-based production systems. 
The greater mean lactation SCC for parity 1 animals compared with parity 2 and $3+$ animals is in contrast with previous research that showed that lactation average SCC increased as parity increased (McCarthy et al., 2007; Walsh et al., 2007), although parity did not affect the incidence of mastitis. It is unclear why parity 1 animals had a greater mean lactation SCC than greater-parity animals; however, the overall mean SCC among parities was below the 100,000 cells $/ \mathrm{mL}$ that would indicate subclinical infection (Ruegg and Pantoja, 2013). Therefore, it is unlikely that differences in mean SCC among parities had an effect on milk production.

\section{CONCLUSIONS}

Holstein-Friesian cows in this study had higher milk yields compared with JEX and 3-way cows; however, HF and JEX had similar MSo yield, with 3-way having slightly lower MSo yield than JEX. High levels of reproductive performance were achieved for all 3 genotypes. There was evidence of crossbreeding benefits in terms of the efficiency of MSo production per kilogram of metabolic BW. Holstein-Friesian herds with poor reproductive performance and low milk fat and protein contents are likely to benefit considerably from crossbreeding with high-EBI Jersey bulls, with all herds likely to benefit in terms of production efficiency. However, where herd performance, particularly in relation to reproductive performance, is comparable with the HF in the current study, crossbreeding with Jersey or Norwegian Red is unlikely to lead to significant improvements in overall herd performance. The combination of similar MSo production, reproductive performance, and health traits made all 3 genotypes suitable for spring-calving, pasture-based milk production systems.

\section{ACKNOWLEDGMENTS}

This research was funded by the Irish Dairy Levy administered by Dairy Research Ireland (Dublin, Ireland). The first author received a Teagasc Walsh Scholarship. The authors gratefully acknowledge the invaluable assistance of the farm and technical staff based at Teagasc Clonakilty and Teagasc Moorepark (both in Co. Cork, Ireland). The authors declare that they have no conflicts of interest.

\section{REFERENCES}

AOAC (Association of Official Analytical Chemists). 1990. Pages 777800 in Official Methods of Analysis. Vol. 2. Association of Official Analytical Chemists, Arlington, VA.
Auldist, M. J., M. Pyman, C. Grainger, and K. Macmillan. 2007. Comparative reproductive performance and early lactation productivity of Jersey $\times$ Holstein cows in predominantly Holstein herds in a pasture-based dairying system. J. Dairy Sci. 90:4856-4862. https:/ /doi.org/10.3168/jds.2006-869.

Beecher, M., F. Buckley, S. M. Waters, T. Boland, D. Enriquez-Hidalgo, M. Deighton, M. O'Donovan, and E. Lewis. 2014. Gastrointestinal tract size, total-tract digestibility, and rumen microflora in different dairy cow genotypes. J. Dairy Sci. 97:3906-3917. https:/ /doi.org/10.3168/jds.2013-7708.

Begley, N., K. Pierce, and F. Buckley. 2009. Milk production, udder health, body condition score and fertility performance of HolsteinFriesian, Norwegian Red and Norwegian Red $\times$ Holstein-Friesian cows on Irish farms. Pages 191-198 in Breeding for Robustness in Cattle. EAAP Publication No. 126. Wageningen Academic Publishers, Wageningen, the Netherlands.

Berry, D., L. Shalloo, A. Cromie, V. Olori, and P. Amer. 2005. Economic Breeding Index for Dairy Cattle in Ireland. Irish Cattle Breeding Federation, Bandon, Cork, Ireland.

Berry, D., L. Shalloo, V. Olori, and P. Dillon. 2004. Revision of economic values for traits within the economic breeding index. Accessed Dec. 9, 2019. http://www.icbf.com/publications/files/EBI _Revision_feb04.pdf.

Berry, D. P. 2015. Breeding the dairy cow of the future: What do we need? Anim. Prod. Sci. 55:823-837. https://doi.org/10.1071/ AN14835.

Berry, D. P., J. F. Kearney, K. Twomey, and R. D. Evans. 2013. Genetics of reproductive performance in seasonal calving dairy cattle production systems. Ir. J. Agric. Food Res. 52:1-16.

Bjelland, D. W., K. Weigel, P. Hoffman, N. Esser, W. Coblentz, and T. Halbach. 2011. Production, reproduction, health, and growth traits in backcross Holstein $\times$ Jersey cows and their Holstein contemporaries. J. Dairy Sci. 94:5194-5203. https://doi.org/10.3168/ jds.2011-4300.

Booth, C. J., L. Warnick, Y. Gröhn, D. Maizon, C. Guard, and D. Janssen. 2004. Effect of lameness on culling in dairy cows. J. Dairy Sci. 87:4115-4122. https://doi.org/10.3168/jds.S0022 -0302(04)73554-7.

Buckley, F., N. Lopez-Villalobos, and B. Heins. 2014. Crossbreeding: Implications for dairy cow fertility and survival. Animal 8(Suppl. 1):122-133. https://doi.org/10.1017/S1751731114000901.

Coffey, E. L., L. Delaby, S. Fitzgerald, N. Galvin, K. M. Pierce, and B. Horan. 2017. Effect of stocking rate and animal genotype on dry matter intake, milk production, body weight, and body condition score in spring-calving, grass-fed dairy cows. J. Dairy Sci. 100:7556-7568. https://doi.org/10.3168/jds.2017-12672.

Coffey, E. L., B. Horan, R. D. Evans, and D. P. Berry. 2016. Milk production and fertility performance of Holstein, Friesian, and Jersey purebred cows and their respective crosses in seasonal-calving commercial farms. J. Dairy Sci. 99:5681-5689. https://doi.org/10 $.3168 /$ jds.2015-10530.

Cummins, S. B., P. Lonergan, A. Evans, D. P. Berry, R. D. Evans, and S. T. Butler. 2012. Genetic merit for fertility traits in Holstein cows: I. Production characteristics and reproductive efficiency in a pasture-based system. J. Dairy Sci. 95:1310-1322. https://doi.org/ $10.3168 /$ jds.2011-4742.

DAFM. 2018. AIM Bovine Statistics Report. Accessed Aug. 19, 2019. https://www.agriculture.gov.ie/media/migration/ animalhealthwelfare/ animalidentificationandmovement/ AIMBovineStatisticsReport2018100519.pdf.

Delaby, L., F. Buckley, N. McHugh, and F. Blanc. 2018. Robust animals for grass-based production systems. Sustainable meat and milk production from grasslands. Pages $389-400$ in Proc. 27th General Meeting of the European Grassland Federation, Cork, Ireland. European Grassland Federation, Zürich, Switzerland.

Delaby, L., and B. Horan. 2017. Improved efficiency in temperate grass based dairy systems. In Proc. Annual Meeting of the Brazilian Society of Animal Science, Foz do Iguaçu, Brazil.

Department of Agriculture. 2014. AIM bovine statistics annual report. Accessed Aug. 20, 2019. https: 
/ / www .agriculture.gov.ie/media/migration/ animalhealthwelfare/ animalidentificationandmovement/ c a t t l e m o ve me n t m o n i t o r i n g s y s t e m / AIMBovineStatisticsReport2014050615.pdf.

Edmonson, A. J., I. J. Lean, L. D. Weaver, T. Farver, and G. Webster. 1989. A body condition scoring chart for Holstein dairy cows. J. Dairy Sci. 72:68-78. https://doi.org/10.3168/jds.S0022 -0302(89)79081-0.

Ferris, C. P., P. Purcell, A. Gordon, T. Larsen, and M. Vestergaard. 2018. Performance of Holstein and Swedish-Red $\times$ Jersey/Holstein crossbred dairy cows within low- and medium-concentrate grassland-based systems. J. Dairy Sci. 101:7258-7273. https://doi .org/10.3168/jds.2017-14107.

Friggens, N. C., F. Blanc, D. P. Berry, and L. Puillet. 2017. Review: Deciphering animal robustness. A synthesis to facilitate its use in livestock breeding and management. Animal 11:2237-2251. https: //doi.org/10.1017/S175173111700088X.

Green, L. E., V. Hedges, Y. Schukken, R. Blowey, and A. Packington. 2002. The impact of clinical lameness on the milk yield of dairy cows. J. Dairy Sci. 85:2250-2256. https://doi.org/10.3168/ jds.S0022-0302(02)74304-X.

Hanrahan, L., A. Geoghegan, M. O'Donovan, V. Griffith, E. Ruelle, M. Wallace, and L. Shalloo. 2017. PastureBase Ireland: A grassland decision support system and national database. Comput. Electron. Agric. 136:193-201. https://doi.org/10.1016/j.compag .2017.01.029.

Hazel, A. R., B. Heins, A. Seykora, and L. Hansen. 2014. Production, fertility, survival, and body measurements of Montbéliarde-sired crossbreds compared with pure Holsteins during their first 5 lactations. J. Dairy Sci. 97:2512-2525. https://doi.org/10.3168/jds .2013-7063.

Heins, B. J., L. Hansen, and A. Seykora. 2006. Production of pure Holsteins versus crossbreds of Holstein with Normande, Montbeliarde, and Scandinavian Red. J. Dairy Sci. 89:2799-2804. https:/ /doi.org/10.3168/jds.S0022-0302(06)72356-6.

Heins, B. J., L. Hansen, A. Seykora, A. Hazel, D. Johnson, and J. Linn. 2008. Crossbreds of Jersey $\times$ Holstein compared with pure Holsteins for body weight, body condition score, dry matter intake, and feed efficiency during the first one hundred fifty days of first lactation. J. Dairy Sci. 91:3716-3722. https://doi.org/10 $.3168 /$ jds.2008-1094.

Horan, B., P. Dillon, D. Berry, P. O'Connor, and M. Rath. 2005. The effect of strain of Holstein-Friesian, feeding system and parity on lactation curves characteristics of spring-calving dairy cows. Livest. Prod. Sci. 95:231-241. https://doi.org/10.1016/j.livprodsci 2004.12.021.

ICBF (Irish Cattle Breeding Federation). 2019a. Dairy calving statistics. Accessed Jun. 21, 2019. https://www.icbf.com/wp/wp -content/uploads/2018/09/Dairy-Calving-Stats-2018-1.pdf.

ICBF (Irish Cattle Breeding Federation). 2019b. EBI increases on average $€ 9$ per year. Accessed Jun. 21, 2019. https://www.icbf.com/ $\mathrm{wp} / \mathrm{p}=12466$.

Kennedy, E., M. McEvoy, J. Murphy, and M. O'Donovan. 2009. Effect of restricted access time to pasture on dairy cow milk production, grazing behavior, and dry matter intake. J. Dairy Sci. 92:168-176. https://doi.org/10.3168/jds.2008-1091.

Leane, S. 2016. Nutritional effects on reproduction in pasture-based systems of dairy production. PhD Dissertation. University College Dublin, Dublin, Ireland.

Lopez-Villalobos, N., D. J. Garrick, C. W. Holmes, H. T. Blair, and R. J. Spelman. 2000. Profitabilities of some mating systems for dairy herds in New Zealand. J. Dairy Sci. 83:144-153. https://doi.org/ 10.3168/jds.S0022-0302(00)74865-X.

Mackle, T., C. Parr, G. Stakelum, A. Bryant, and K. MacMillan. 1996. Feed conversion efficiency, daily pasture intake, and milk production of primiparous Friesian and Jersey cows calved at two different liveweights. N. Z. J. Agric. Res. 39:357-370. https://doi.org/ 10.1080/00288233.1996.9513195.

McCarthy, S., B. Horan, P. Dillon, P. O'Connor, M. Rath, and L. Shalloo. 2007. Economic comparison of divergent strains of Holstein-Friesian cows in various pasture-based production systems.
J. Dairy Sci. 90:1493-1505. https://doi.org/10.3168/jds.S0022 -0302(07)71635-1.

McClearn, B., T. Gilliland, L. Delaby, C. Guy, M. Dineen, F. Coughlan, and B. McCarthy. 2019. Milk production per cow and per hectare of spring calving dairy cows grazing swards differing in Lolium perenne L. ploidy and Trifolium repens L. composition. J. Dairy Sci. 102:8571-8585. https://doi.org/10.3168/jds.2018-16184. Mee, J. F. 2008. Prevalence and risk factors for dystocia in dairy cattle: A review. Vet. J. 176:93-101. https://doi.org/10.1016/j.tvjl .2007.12.032.

Moore, S. G., T. Fair, P. Lonergan, and S. Butler. 2014. Genetic merit for fertility traits in Holstein cows: IV. Transition period, uterine health, and resumption of cyclicity. J. Dairy Sci. 97:2740-2752. https://doi.org/10.3168/jds.2013-7278.

Morgan, D., G. Stakelum, and J. Dwyer. 1989. Modified neutral detergent cellulase digestibility procedure for use with the 'Fibertec' system. Isr. J. Agric. Res. 28:91-92.

O'Sullivan, M., S. T. Butler, K. M. Pierce, M. Crowe, K. O'Sullivan, R. Fitzgerald, and F. Buckley. 2020. Reproductive efficiency and survival of Holstein-Friesian cows of divergent Economic Breeding Index, evaluated under seasonal calving pasture-based management. J. Dairy Sci. 103:1685-1700.

O'Sullivan, M., P. Dillon, K. O'Sullivan, K. M. Pierce, N. Galvin, M. Egan, and F. Buckley. 2019. Intake, efficiency, and feeding behavior characteristics of Holstein-Friesian cows of divergent Economic Breeding Index evaluated under contrasting pasture-based feeding treatments. J. Dairy Sci. 102:8234-8246. https://doi.org/10.3168/ jds.2019-16371.

Prendiville, R., K. Pierce, and F. Buckley. 2009. An evaluation of production efficiencies among lactating Holstein-Friesian, Jersey, and Jersey $\times$ Holstein-Friesian cows at pasture. J. Dairy Sci. 92:6176-6185

Prendiville, R., K. Pierce, and F. Buckley. 2010. A comparison between Holstein-Friesian and Jersey dairy cows and their F1 cross with regard to milk yield, somatic cell score, mastitis, and milking characteristics under grazing conditions. J. Dairy Sci. 93:27412750. https://doi.org/10.3168/jds.2009-2791.

Prendiville, R., L. Shalloo, K. M. Pierce, and F. Buckley. 2011. Comparative performance and economic appraisal of Holstein-Friesian, Jersey and Jersey $\times$ Holstein-Friesian cows under seasonal pasturebased management. Ir. J. Agric. Food Res. 50:123-140.

Pryce, J. E., B. I. Nielsen, R. F. Veerkamp, and G. Simm. 1999. Genotype and feeding system effects and interactions for health and fertility traits in dairy cattle. Livest. Prod. Sci. 57:193-201. https: //doi.org/10.1016/S0301-6226(98)00180-8.

Ranjbar, S., A. Rabiee, A. Gunn, and J. House. 2016. Identifying risk factors associated with lameness in pasture-based dairy herds. J. Dairy Sci. 99:7495-7505. https://doi.org/10.3168/jds.2016-11142.

Ruegg, P. L., and J. C. F. Pantoja. 2013. Understanding and using somatic cell counts to improve milk quality. Ir. J. Agric. Food Res. $52: 101-117$.

Shalloo, L., A. Cromie, and N. McHugh. 2014. Effect of fertility on the economics of pasture-based dairy systems. Animal 8(Suppl. 1):222-231. https://doi.org/10.1017/S1751731114000615.

Shonka-Martin, B. N., A. Hazel, B. Heins, and L. B. Hansen. 2019. Three-breed rotational crossbreds of Montbéliarde, Viking Red, and Holstein compared with Holstein cows for dry matter intake, body traits, and production. J. Dairy Sci. 102:871-882. https://doi .org/10.3168/jds.2018-15318.

Sørensen, M. K. 2007. Crossbreeding-An important part of sustainable breeding in dairy cattle and possibilities for implementation. Pages 29-40 in Proc. Crossbreeding of Dairy Cattle: The Science and the Impact. 4th Biennial WE Petersen Symposium, University of Minnesota, St. Paul. Accessed Mar. 18, 2020. https://pdfs.semanticscholar.org/064c/ 2c6bd1384c0bfb699a8ee4b981a728b0d14e.pdf.

Tyrrell, H. F., and J. T. Reid. 1965. Prediction of the energy value of cows' milk. J. Dairy Sci. 48:1215-1223.

Van Soest, P. J. 1963. Use of detergents in the analysis of fibrous feeds. 2. A rapid method for the determination of fiber and lignin. J. Assoc. Off. Agric. Chem. 46:829-835. 
Vance, E., C. Ferris, C. Elliott, H. Hartley, and D. Kilpatrick. 2013. Comparison of the performance of Holstein-Friesian and Jersey $\times$ Holstein-Friesian crossbred dairy cows within three contrasting grassland-based systems of milk production. Livest. Sci. 151:66-79. https://doi.org/10.1016/j.livsci.2012.10.011.

Vance, E. R., C. Ferris, C. Elliott, S. McGettrick, and D. Kilpatrick. 2012. Food intake, milk production, and tissue changes of Holstein-Friesian and Jersey $\times$ Holstein-Friesian dairy cows within a medium-input grazing system and a high-input total confinement system. J. Dairy Sci. 95:1527-1544. https://doi.org/10.3168/ jds.2011-4410.

VanRaden, P. M., and A. Sanders. 2003. Economic merit of crossbred and purebred US dairy cattle. J. Dairy Sci. 86:1036-1044. https: /doi.org/10.3168/jds.S0022-0302(03)73687-X.

Veerkamp, R., L. Kaal, Y. De Haas, and J. Oldham. 2013. Breeding for robust cows that produce healthier milk: RoBustMiLk. Adv. Anim. Biosci. 4:594-599. https://doi.org/10.1017/S2040470013000149.

Walsh, S., F. Buckley, D. Berry, M. Rath, K. Pierce, N. Byrne, and P. Dillon. 2007. Effects of breed, feeding system, and parity on ud- der health and milking characteristics. J. Dairy Sci. 90:5767-5779. https://doi.org/10.3168/jds.2007-0389.

Walsh, S., F. Buckley, K. Pierce, N. Byrne, J. Patton, and P. Dillon. 2008. Effects of breed and feeding system on milk production, body weight, body condition score, reproductive performance, and postpartum ovarian function. J. Dairy Sci. 91:4401-4413. https:/ doi.org/10.3168/jds.2007-0818.

White, T. L. 2001. Reproductive performance of Holstein-Friesian $\times$ Jersey crossbreds in predominantly Holstein herds. PhD Dissertation. The University of Melbourne, Australia.

\section{ORCIDS}

B. McClearn () https://orcid.org/0000-0002-6370-705X

T. J. Gilliland $\odot$ https://orcid.org/0000-0002-4514-1435

M. Dineen ( https://orcid.org/0000-0003-4585-2680 